\title{
BUCCINUM TUBEROSUM.
}

Q

\section{CHARACTER GENERICUS.}

Animal Limax.

Testa univalvis, spiralis, gibbosa.

Apertura ovata, desinens in canaliculum (s. retusam lacunam) dextrum, cauda retusum. Labium interius explanatum.

$$
\text { Lin. Syst. Nat. p. } 1196 .
$$

Character SPecificus, Ëc.

BUCCINUM testa cingulis duobus tuberculosis, cauda recurva.

$$
\text { Lin. Syst. Nat. p. } 1198 .
$$

Gualt. test. t. 41. f. A.

Seb. mus. 3. t. 73. f. 5-15.

Knorr. Vergn. 3. t. 10. f. 1. 2.

In Oceano Americano præcipue innascitur Buccinum tuberosum, magnitudine et coloribus varians, et interdum fere in pedalem crescens longitudinem. 




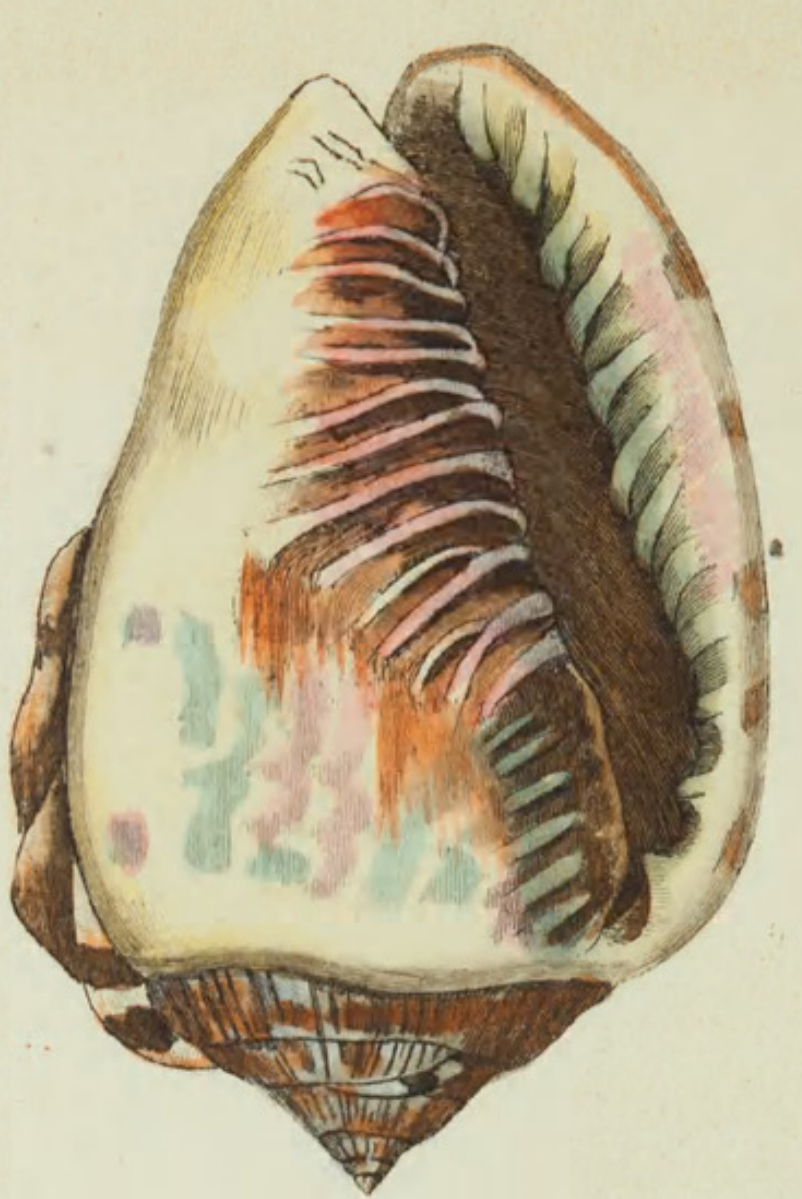

467

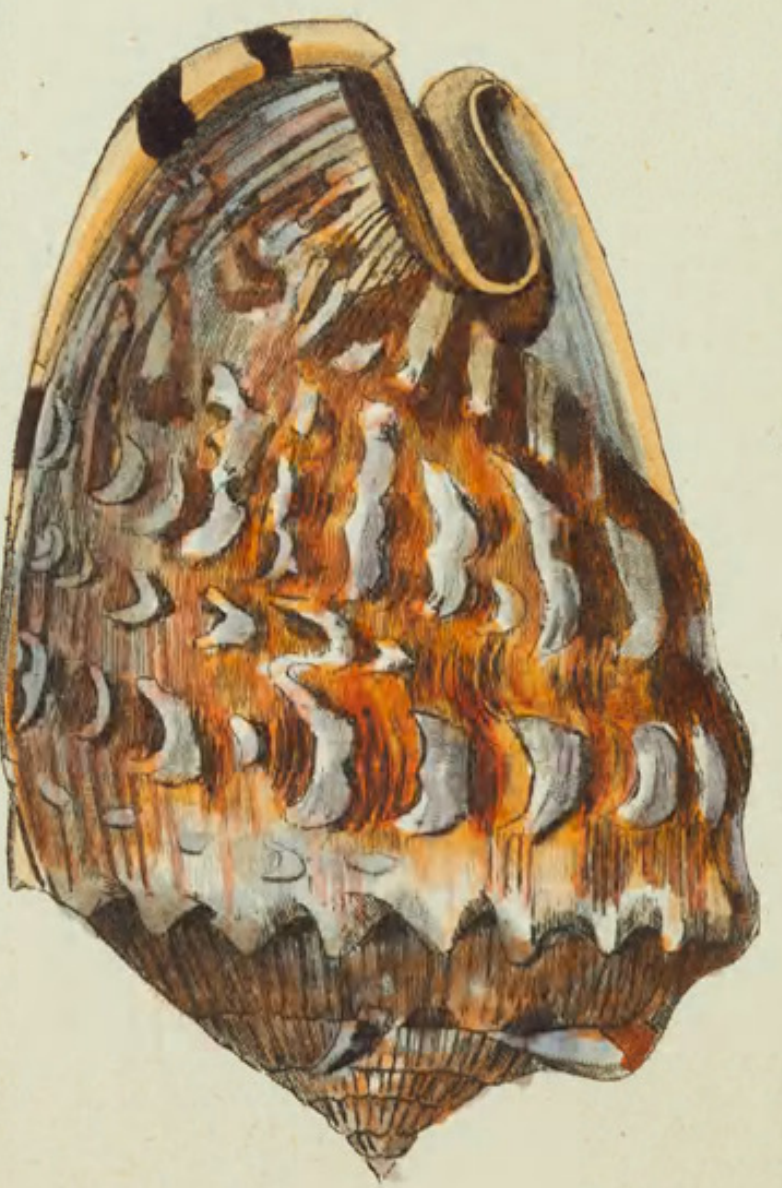




\section{TUBEROUS BUCCINUM.}

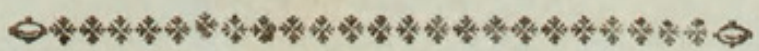

\section{GENERIC CHARACTER.}

Animal allied to a Slug.

Shell univalve, spiral, gibbous.

Aperture ovate, ending in a channel pointing towards the right.

Interior Lip expanded.

$$
\text { SPECIFIC CHARACTER, छ̈C. }
$$

Pale BUCCINUM with rufous and dusky variegations, two rows of tubercles, and recurved tip.

Knobbed BUCCINUM,

The shell here represented is a native of the American scas, and varies greatly both in size and colors, sometimes measuring almost twelve inches in length, 


\section{$2 \mathrm{BHL}$ Biodiversity Heritage Library}

Shaw, George. 1801. "Tuberous Buccinum, Buccinum tuberosum [PI. 467]." The Naturalist's Miscellany 12(CXLIV), https://doi.org/10.5962/p.310913.

View This Item Online: https://www.biodiversitylibrary.org/item/278722

DOI: https://doi.org/10.5962/p.310913

Permalink: https://www.biodiversitylibrary.org/partpdf/310913

\section{Holding Institution}

Museums Victoria

\section{Sponsored by}

Atlas of Living Australia

\section{Copyright \& Reuse}

Copyright Status: Public domain. The BHL considers that this work is no longer under copyright protection.

This document was created from content at the Biodiversity Heritage Library, the world's largest open access digital library for biodiversity literature and archives. Visit BHL at https://www.biodiversitylibrary.org. 